\title{
ILF2 Gene
}

National Cancer Institute

\section{Source}

National Cancer Institute. ILF2 Gene. NCI Thesaurus. Code C140300.

This gene plays a role in mRNA localization, DNA repair and the regulation of IL2 gene expression. 